\title{
The Torch Press: A Preliminary History
}

\author{
THOMAS L. CAR N E Y \\ and JOYCE CRAWFORD
}

"There is properly no history, only biography." If this statement by Ralph Waldo Emerson is correct, then the historical account of The Torch Press in Cedar Rapids, Iowa, must lie principally in the lives of Luther A. Brewer and Edward F. Misak. Brewer was the founder and president of the press, and he was succeeded as president by Edward Misak. Other individuals who were associated with the Republican Printing Company in Cedar Rapids played a lesser role in the history of The Torch Press, among them Frederick J. Lazell, William Harvey Miner, and Cyrenus Cole.

Luther Albertus Brewer was born in Welsh Run, Pennsylvania, on December 17, 1858. He graduated from Pennsylvania College at Gettysburg in 1883, and for a brief time was the principal of a school in Boonesboro, Maryland, before moving to Spencer, Iowa, to work as a teller at the Clay County Bank. In 1884 his fortunes led him to Cedar Rapids, Iowa, where he studied law and later became a bookkeeper for a local coal firm. Brewer was to live in Cedar Rapids for the rest of his life, and his relationship with the city was mutually beneficial. He was a founder and second president of the Cedar Rapids Rotary Club; he held appointments as state oil inspector and president of the Cedar Rapids Art Association; and he was a member of the first Board of Trustees of the Cedar Rapids Public Library.

He accepted the position of city editor for the Republican Printing Company's Daily Republican newspaper in 1887, and two years later he became the assistant business manager for the printing company. In 1894 Johnson Brigham, who later became the state librarian, sold his interest in the Republican Printing Company to Luther Brewer, W. R. Boyd, and L. S. Merchant. (Merchant already owned a substantial interest in the company.) In the reorganization that followed this sale, Brewer was named business manager for the company and, among his 
other duties, he began to develop a book-binding and job-printing department within the company.

The year 1898 marked Brewer's marriage to Elinore Taylor of Cedar Rapids and also the sale of the Republican Printing Company by its three proprietors to H. G. McMillan and Cyrenus Cole. McMillan, of Rock Rapids, was then U.S. Attorney for the northern district of Iowa, and Cole was a newspaperman and historian who later served as a U.S. Congressman from Iowa. Brewer remained in his position as business manager for the company. ${ }^{1}$

In 1907 Brewer left the printing company to open a book-making plant of his own, which he named The Torch Press. ${ }^{2}$ In July of the same year, The Torch Press bought McMillan's interest in the Republican Printing Company. The building occupied by the printing company on Second Avenue S.E. proved to be too small for the combined operations of The Torch Press and the Republican Printing Company, and so a new four-story building, projected for occupancy on May 1 , 1908, was erected on the northeast corner of Fourth Avenue and Third Street S.E. Brewer devoted most of his time to The Torch Press concerns, while management of the newspaper business was handled by E. M. Maggart.

In addition to printing the Daily Republican and the Evening Times, the presses rolled out such other publications as the Modern Brotherhood; Little Merchant; Western Poultry Journal; Republican and Times City Directory for Cedar Rapids, Marion and Kenwood, Iova (1910); Cedar Rapids telephone books; and, for more than forty years, the Mississippi Valley Historical Review.

The new structure also housed The Torch Press Book Shop (ca. 1909-1917), which was supervised by William Harvey Miner. A native of New Haven, Connecticut, and a man of varied interests and travels, Miner had already written several books published by Burrows of Cleveland, a firm for which Brewer had earlier done job work. The Torch Press Book Shop was a natural outgrowth of Brewer's interests

1 From 1900 to 1907 Luther Brewer also served as a part-time lecturer on journalism at The University of Iowa. He drove to Iowa City in a buggy twice a week to teach courses on the history of books and printing and on the writing of news and editorials. Typescripts of several of his course lectures are preserved in the University Archives.

2 Publications bearing the imprint of The Torch Press are dated as early as 1905. In 1904 Brewer printed on handmade paper twenty copies of Frederick C. Hicks's edition of Thomas Hutchins' A Topographical Description of Virginia Pennsyliania, Maryland, and North Carolina (Cleveland: The Burrows Brothers Company, 1904). The associntion of this volume with Brewer's press is indicated in a letter from Hicks to Brewer, dated March 11, 1905, owned by the University of Iowa Libraries. 
and, in 1911, was described as the biggest and most largely patronized book shop west of Chicago. In addition to regular retail walk-in trade, the shop issued catalogs for its customers. The key offering of catalog number thirteen was a collection of Abraham Lincoln ephemera: ". . . telegrams (69) issued by the Navy department and Allied Bureaus of the U.S. Government . . . covering the capture of the conspirators and assassins ... [along with] . . further collection (23) of similar material devoted wholly to the Assassination and Funeral of the President . . . \$1,000.00." Also offered for sale for $\$ 150$ was Dickens' personal copy of an 1855 edition of "A Christmas Carol," with a bold signature of Charles Dickens and date of receipt on the title page.

At the time of the Cole-McMillan purchase of the Republican Printing Company in 1898, Frederick John Lazell worked as the firm's telegraph editor. Lazell did not limit his activity to the area indicated by his title, but worked in all departments of the newspaper. Multitalented, later professor of journalism at The University of Iowa, ${ }^{3}$ Lazell added to the list of early Torch Press imprints with a four-book series which indicates his interest in nature studies: Some Winter Days in lowa, 1907; Some Spring Days in Iowa, 1908; Some Summer Days in Iowa, 1909; and Some Autumn Days in Iowa, 1911. (This last title had also been used in 1906 for a book with a different text.) Perhaps Lazell's most significant contributions to The Torch Press were his annual reviews in the Republican of Brewer's Christmas books. His reviews provide a record of their inception and chronicle Brewer's intent to distribute these publications and share with his friends a consuming and jovful absorption with his growing Leigh Hunt collection.

Disillusioned by political turns after the election of 1912 , in near despair of continued newspaper success without E. M. Maggart, who had accepted employment elsewhere, Cyrenus Cole, editor and partowner of the Republican, was eager to leave the printing company and resume writing books. ${ }^{4}$ About 1914 Cole sold his half of the properties to Brewer, but protests from Brewer and pleas from other locally influential men persuaded Cole to remain in an editorial capacity

3 Lazell was appointed to the University of Iowa faculty in 1924, at the time the School of Journalism was established. He joined a journalism faculty which then included George Gallup, William Maulsby, and C. H. Weller, and he continued teaching at Iowa until 1937.

4 He had previously written The Farmer in Politics and Prosperity (ca. 1900), published by the Republican Printing Company, as well as The Two Great Canyons (1908) and Anna Marcella's Book of Verses (1912), both Torch Press imprints. One of the prospective books was A History of the People of Iowa, published by The Torch Press in 1921. Later be would write I Remember, I Remember (1936), also printed by The Torch Press, and a history of the Indian Black Hawk, I Am a Man (1938), published by the State Historical Society of Iowa. 
for the next seven years. Upon Cole's election to Congress in 1921, the editorship of the Republican devolved upon Lazell. In October, 1922, Brewer sold the Republican to Colonel William G. Dows and his associates, but continued to print the paper until its merger with the Cedar Rapids Gazette in 1927, several months after Dows' death.

Brewer's brother-in-law, William M. Deacon, first associated with The Torch Press in 1920 as business manager, became treasurer following the sale of the newspaper, and Edward F. Misak, previously plant superintendent, became vice-president. Brewer retained the presidency of The Torch Press, as he had since its inception, and Mrs. Brewer remained as secretary. Within a few years, however, Brewer disposed of most of his interests in The Torch Press, keeping a vicepresidency. In 1929 Edward Misak became president, and Deacon assumed the additional capacity of secretary until his retirement in 1936.

Less encumbered by business responsibilities, Brewer concentrated even more on his widely known and unique collection of books and manuscripts by the nineteenth-century English poet and essayist Leigh Hunt, an interest shared with his friends in several of the Christmas books and purposefully pursued for the remainder of his life. He compiled and in 1932 published, under the Torch Press imprint, My Leigh Hunt Library: The First Editions, limited to 125 copies. This book marked the zenith of Brewer's years of collecting. The second volume, My Leigh Hunt Library: The Holograph Letters, published by the University of Iowa Press in 1938, was likewise printed at The Torch Press.

By the early 1930's certain of Brewer's treasured friends were gone, among them William Howard Taft, a former United States President whose visits to Cedar Rapids were so frequent and enjoyable that Taft once called the city another home town, and Willard C. Stuckslager, banker, state senator, and fellow collector, who had financed the ColeMcMillan purchase of the Republican Printing Company. These losses might have been preparatory, but Brewer barely endured the death of his wife, Elinore, the patient illuminator of the earliest Christmas books and of his life. Never much separated from her, Brewer died scarcely two months later on May 6, 1933. His extensive Leigh Hunt collection was to find a suitable and enduring home in the University of Iowa Libraries. 5

Though the decade of the 1920's had been its golden era for limited editions, The Torch Press, after the death of Luther Brewer, continued

5 See Frank S. Hanlin, "The Brewer-Leigh Hunt Collection at the State University of Iowa," Keats-Shelley Joumal, 8 (1959), pp. 91-94. Also O M Brack. Jr., and D. H. Stefanson, A Catalogue of the Leigh Hunt Manuscripts in the University of lowa Libraries (Iowa City: Friends of the University of Iowa Libraries, 1973). 
to operate effectively under the direction of Edward Misak. ${ }^{6}$ Edward Frank Misak had been born in Lodz, Poland, on May 20, 1884. He came to the United States in 1891, graduated from Washington High School in Cedar Rapids, and attended the Cedar Rapids Business College from 1900-1901. He married Bess Florence Stepanek on September 9, 1909, and they had two daughters, Marcella and Margaret.

Edward Misak's life was almost totally involved with printing and publishing. He had started as a newsboy at the Republican, and about the time of the Cole-McMillan purchase of the Republican Printing Company he began as an apprentice pressman at three dollars a week. He was employed in the pressroom through 1916, having been retained when The Torch Press acquired the Republican Printing Company. Misak was the superintendent through 1924, served as vice-president of The Torch Press from 1924-1929, and then became president, in which capacity he remained for the next thirty years.

Employees of The Torch Press during its last years remember him nearly breathing his life into the tired old presses, remember his pride in the imported paper stock (dating perhaps from Brewer's time), and remember the elderly former apprentice taking an occasional turn at the presses, his youthful skills unforgotten.

The Torch Press, sole survivor of the enterprises associated with the Republican Printing Company, did not long outlive the death of Edward Misak in 1959. Its affairs were concluded by Misak's son-in-law, Paul Strain. The Torch Press reflects to some degree the Midwest's own history, conceived of an easterner's dream and carried through maturity by an immigrant's determination. Its imprints are as scattered as the descendants of a pioneer family. Until its former site was occupied in 1966 by the Cedar Rapids Art Association, the building stood empty, a silent reproach to a generation which had failed to provide a replacement for the imaginative and creative leadership of Luther A. Brewer and Edward F. Misak. Appropriately, a small collection of the Torch Press Christmas books is now preserved in the Herbert S. Stamats Art Library of the Cedar Rapids Art Association, in the same building which housed The Torch Press for over half a century. ${ }^{7}$

It would be an enormous undertaking to compile a complete bibli-

6 Beginning in 1941 The Torch Press introduced and housed the Miniature Print Society. Membership in the Society was limited to 200 individuals. In addition to receiving three original signed proofs by prominent contemporary artists each year at no cost other than the annual dues of ten dollars, members were also entitled to purchase other prints periodically offered for sale.

7 A complete set of the Torch Press Christmas books is owned by the University of Iowa Libraries. 
ography of books published or printed by The Torch Press during its half century of operation. The following checklists are confined to three major areas of collectible publications: (I) The Torch Press Christmas books, (II) the T. Henry Foster Christmas books, and (III) those limited editions printed at The Torch Press which carry a stated numerical limitation.

Among the most interesting and intriguing books are those which comprise The Torch Press Christmas series. Brewer began this tradition in 1912 when he published seventy copies of a small volume entitled The Divine Art of Contentment. With only two exceptions, one occasioned by World War I in 1918 and the other in 1934, presumably caused by Brewer's death the previous year, the series continued annually until the final volume was issued for Christmas, 1959. The Christmas series comprises those books, usually printed in December of each year, which were distributed to the friends of The Torch Press at Christmas time. The forty-six books in this series are designated as privately printed for the friends of Luther A. Brewer or Brewer and his wife or The Torch Press. Binding variants are known to have occurred, and the authors have described the binding of the particular volumes they examined.

From 1945 through 1951 The Torch Press also printed a Christmas series for the friends of May and T. Henry Foster. Mr. Foster was a prominent businessman and book collector of Ottumwa, Iowa. The Foster series is confusingly similar in design and format to The Torch Press Christmas books, and the present checklist may assist in distinguishing the two series.

The third checklist, consisting of limited editions, will indicate other areas of interest that figured prominently in the work of The Torch Press. To a zealous collector this listing may hint as well at trails beyond the limited editions that might fruitfully be pursued.

Among these limited editions are titles done by The Torch Press for such groups as the Bookfellows of Chicago (Luther Brewer was Bookfellow number 14), the Bibliophiles of Boston, and the Rowfant Club of Cleveland. For the noted Chicago bookman Walter M. Hill, The Torch Press printed not only limited editions but sale catalogs and an occasional Christmas volume. ${ }^{8}$

The bibliographies that were printed at The Torch Press constitute a significant endeavor, and they include not only the author bibliographies done for the Centaur Bookshop-on Lawrence, Cabell, Dreiser, Van Vechten and others-but also the Oakleaf bibliography on Abra-

8 Vincent Starrett's The Unique Hamlet (1920) is an elusive example of a Walter M. Hill Christmas book that was printed at The Torch Press. 
ham Lincoln, the J. Christian Bay handfuls of western books, and Luther Brewer's volumes on his Leigh Hunt library.

And beyond these limited editions, for those who care to seek, can be found a remarkable array of historical volumes. There is Frederick H. Dyer's massive Compendium of the War of the Rebellion (1908); there is William E. Connelley's Quantrill and the Border Wars (1910) and General E. A. Hitchcock's A Traveler in Indian Territory (1930); there is Dorothy Dondore's The Prairie and the Making of Middle America (1926) and The Indian Wars of Minnesota (1956) by Louis H. Roddis; there is Ralph E. Twitchell's The Leading Facts of New Mexican History (1911-1912) and his Spanish Archives of New Mexico (1914); there is Grant Foreman's Pioneer Days in the Early Southwest (1926) and Cyrenus Cole's A History of the People of lowa (1921) and Iowa Through the Years (1940); and, not least, there is Luther Brewer's twovolume History of Linn County, lowa (1911)..$^{9}$ From its half century and more of printing and publishing, The Torch Press has left us a legacy of well-made books that thread through the years in a bright ribbon of Americana.

THE TORCH PRESS CHRISTMAS SERIES (1912-1959)

1912

THE DIVINE ART OF CONTENTMENT (excerpt from Isaak Walton's Complete [sic] Angler). $20 \times 13 \mathrm{~cm}$; 31 p.; illus.; "/4 vellum; white boards; "Privately printed for Luther A. Brewer and his friends Christmas nineteen twelve"; "only seventy copies printed. Illuminated letter by Elinore Taylor Brewer."

1913

OF A HAPPY LIFE: FROM SENECA'S MORALS (excerpts included are "Of a Happy Life" and "The Blessings of Friendship"). $21.5 \times 15 \mathrm{~cm}$;; 35 p.; tan boards; "Privately printed for the friends of Luther A. and Elinore Taylor Brewer Christmas nineteen-thirteen"; "Seventy-five copies printed. Illuminated initial by Elinore Taylor Brewer."

\section{4}

ABOUT A GREAT BOOK: WITH SOME LITERARY AUTOCRAPHS. $19 \times 12.5$ cm.; 50 p. +26 p.; facsimiles of letters; 30 vellum; tan boards; "Privately printed

9 Luther Brewer and Barthinius Wick co-authored the two-volume History of Linn County in 1911. It was printed by The Torch Press. Several sets indicate publication by The Pioneer Publishing Company of Chicago, while an unspecified number of copies of the first volume name The Torch Press as publisher. This history has recently been reprinted, with the addition of a name index (Evansville, Indiana: Unigraphic, Inc., 1973), through the efforts of the Linn County Heritage Society, Cedar Rapids. 
at Cedar Rapids Iowa for the friends of Luther Albertus and Elinore Taylor Brewer Christrnas nineteen fourteen"; "One hundred and twenty-five copies printed. Illuminated initial by Elinore Taylor Brewer."

1915

THE FASCINATION OF PRINTS: ANOTHER OF OUR HOBBIES. $19.5 \times 13$ cm.; 34 p.; $1 / 4$ vellum; tan boards; "Privately printed at Cedar Rapids Iowa for the friends of Luther Albertus Brewer and Elinore Taylor Brewer Christmas 1915"; "One hundred seventy copies printed by The Torch Press. Frontispiece and title designed, etched, and printed by Charles Butler Keeler. Illuminated initial by Elinore Taylor Brewer. All the work on this book was done in Cedar Rapids, Iowa, in December, 1915."

\section{6}

BESIDE OUR READING LAMP: "A little longer here to stay with Pipe and Book." $22 \times 14.5 \mathrm{~cm}$; 29 p.; $k$ vellum; green boards; "Privately printed at Cedar Rapids Iowa for the friends of Luther Albertus Brewer and Elinore Taylor Brewer: Christmas 1916"; "Of this book one hundred and sixty copies have been printed by The Torch Press. The title page designed, etched, and printed by Charles Butler Keeler. The illuminated initial by Elinore Taylor Brewer. All the work on this book was performed in Cedar Rapids Iowa in December 1916."

1917

BESIDE OUR FIREPLACE. $21.5 \times 15 \mathrm{~cm}$.; 63 p.; 光 vellum; grey boards; "Privately printed at Cedar Rapids lowa for the friends of Luther Albertus and Elinore Taylor Brewer Christmas 1917"; "Of this book one hundred and seventyfive copies have been printed by The Torch Press Cedar Rapids Iowa. The title page and illuminated initial by Elinore Taylor Brewer."

1918

No Christmas book issued this year.

1919

THE ESCAPE OF ALICE: A CHRISTMAS FANTASY by Vincent Starrett. $22 \mathrm{x}$ $14.5 \mathrm{~cm}$.; $28 \mathrm{p}$.; grey wrappers overlaid with brown wrapper, bound with decorative cord; "Privately printed at Cedar Rapids Iowa for the friends of Luther Albertus and Elinore Taylor Brewer Christmas nineteen nineteen"; "Two hundred copies of this book were printed by The Torch Press Cedar Rapids Iowa in the month of December nineteen nineteen."

\section{0}

AROUND THE LIBRAKY TABLE: AN EVENING WITH LEIGH HUNT. $19 \times$ $13 \mathrm{~cm}$; 42 p. +5 p. facsimiles of Hunt letters; 1 vellum; tan boards; "Privately printed for the friends of Luther Albertus and Elinore Taylor Brewer Cedar Rapids Iowa Christmas nineteen hundred twenty"; "Of this book two hundred and twenty-five copies were printed in December nineteen hundred and twenty by The Torch Press Cedar Rapids Iowa."

1921

A STUDENT OF CATALOGUES by Vincent Starrett. Introduction by Luther Albertus Brewer and Elinore Taylor Brewer; $24 \times 15 \mathrm{~cm}$.; 24 p.; $/ /$ vellum; brown boards; "Privately printed for the friends of Luther Albertus and Elinore Taylor Brewer Cedar Rapids Iowa Christmas nineteen twenty-one"; "Of this book two hundred and fifty copies were printed in December nineteen hundred and twentyone by The Torch Press Cedar Rapids Iowa." 
STEVENSON'S PERFECT VIRTUES AS EXEMPLIFIED BY LEIGH HUNT by Luther A. Brewer. $23.5 \times 15.5 \mathrm{~cm}$.; 25 p.; grey boards; brown spine; "Privately printed for the friends of Luther Albertus and Elinore Taylor Brewer Cedar Rapids Iowa Christmas nineteen twenty-two"; "Of this book two hundred and fifty copies were printed in December nineteen hundred and twenty-two by The Torch Press Cedar Rapids Iowa."

THE LOVE OF BOOKS: WITH A REPRINT OF LEIGH HUNT'S ESSAY ON "MY BOOKS" by Luther A. Brewer. $24 \times 15.5 \mathrm{~cm}$; 38 p.; $\%$ vellum; brown hoards; "Privately printed for the friends of Luther Albertus and Elinore Taylor Brewer Cedar Rapids Iowa Christmas nineteen twenty-three"; "Of this book three hundred copies were printed in December nineteen hundred and twentythree by The Torch Press Cedar Rapids Iowa."

1924

SOME LAMB AND BROWNING LETTERS TO LEIGH HUNT by Luther A. Brewer. $20.5 \times 14 \mathrm{~cm}$; 43 p. +13 p. illus. of letters; t vellum; blue boards; "Privately printed for the friends of Luther Albertus and Elinore Taylor Brewer Cedar Rapids Iowa Christmas nineteen twenty-four"; "Of this book three hundred copies were printed in December nineteen hundred and twenty-four by The Torch Press Cedar Rapids Iowa."

1925

WANDERINGS IN LONDON by Luther A. Brewer. $20.5 \times 14 \mathrm{~cm}$.; 60 p.; vellum; grey marbled boards; "Privately printed for the friends of Luther Albertus and Elinore Taylor Brewer Cedar Rapiás Iowa Christmas nineteen twenty-five"; "Of this book three hundred copies were printed in December nineteen hundred and twenty-five by The Torch Press Cedar Rapids."

\section{6}

MARGINALIA by Luther A. Brewer. $24 \times 15 \mathrm{~cm}$.; 48 p. + frontispiece, portrait of Leigh Hunt by Margaret Gillies. "Courtesy National Portrait Gallery, London" +1 unnumbered page, photograph of painting of Leigh Hunt by B. R. Haydon; vellum; grey boards; "Privately printed for the friends of Luther Albertus and Elinore Taylor Brewer Cedar Rapids Iowa Christmas nineteen twenty-six"; "Of this book three hundred copies were printed in December nineteen hundred and twenty-six by The Torch Press Cedar Rapids lowa."

1927

GOLDEN DAYS IN FRANCE by Luther A. Brewer. $20 \times 13.5 \mathrm{~cm}$; 62 p. +4 unnumbered pages of photographs; red, white, and blue decorated cloth boards; "Privately printed for the friends of Luther Albertus and Elinore Taylor Brewer Cedar Rapids Iowa Christmas nineteen twenty-seven"; "Three hundred copies printed."

THE JOYS AND SORROWS OF A BOOK COLLECTOR by Luther A. Brewer. $20 \times 13.5 \mathrm{~cm}$.; 65 p.; gold, blue, green, and silver decorated boards; blue cloth spine; "Privately printed for the friends of Luther Albertus and Elinore Taylor Brewer Cedar Rapids Iowa Christmas nineteen twenty-eight"; "Three hundred copies printed."

SOME LETTERS FROM MY LEIGH HUNT PORTFOLIOS with brief comment by Luther A. Brewer. $20 \times 14 \mathrm{~cm}$.; 96 p.; brown boards; "Privately printed for 
the friends of Luther Albertus and Elinore Taylor Brewer Cedar Rapids Iowa Christmas nineteen twenty-nine"; "Three hundred copies printed."

1930

LEIGH HUNT AND CHARLES DICKENS: THE SKIMPOLE CARICATURE by Luther A. Brewer, $24 \times 16 \mathrm{~cm}$.; 35 p.; $\tan$ boards; tan cloth spine; "Privately printed for the friends of Luther Albertus and Elinore Taylor Brewer Cedar Rapids Iowa Christmas nineteen hundred thirty"; "Three hundred copies printed."

1931

MORE MARGINALIA: BASED ON LEIGH HUNT'S COPY OF HENRY E. NAPIER'S FLORENTINE HISTORY 1846 by A. Francis Trams. Prefatory note by Luther $A$. Brewer and Elinore Taylor Brewer. $23.5 \times 15.5 \mathrm{~cm}$.; 46 p.; pale gold boards; brown cloth spine; "Privately printed for the friends of The Torch Press and of Luther Albertus and Elinore Taylor Brewer Cedar Rapids Iowa Christmas nineteen thirty-one"; "Three hundred twenty-five copies printed in December nineteen thirty-one by The Torch Press Cedar Rapids Iowa."

1932

LEAVES FROM A LEIGH HUNT NOTE-BOOK by Luther A. Brewer. $19 \times 12$ cm.; 39 p.; tan wrappers; "Privately printed for the friends of The Torch Press and of Luther Albertus and Elinore Taylor Brewer Cedar Rapids Iowa Christmas nineteen thirty-two"; "Three hundred twenty-five copies printed in December nineteen thirty-two by The Torch Press Cedar Rapids lowa."

1933

THE LEIGH HUNT COLLECTION OF LUTHER ALBERTUS BREWER by J. Christian Bay. $19 \times 12 \mathrm{~cm}$.; 39 p.; maroon wrappers; "Privately printed for the friends of The Torch Press in memory of Luther Albertus and Elinore Taylor Brewer Cedar Rapids Iowa Christmas nineteen thirty-three"; "Three hundred seventy-five copies printed in December nineteen thirty-three by The Torch Press Cedar Rapids Iowa."

1934

No Christmas book issued for this year.

1935

A HANDFUL OF WESTERN BOOKS by J. Christian Bay. $20 \times 12.5 \mathrm{~cm}$.; 44 p. + frontispiece, facsimile of title page of "The Western Miscellany"; tan decorated boards; brown cloth spine; "Privately printed for the friends of The Torch Press, Cedar Rapids, Iowa, Christmas nineteen hundred thirty-five"; "Three hundred fifty copies printed in December nineteen thirty-five by The Torch Cedar Rapids Iowa."

1936

A SECOND HANDFUL OF WESTERN BOOKS by J. Christian Bay. "The contents of this book were included in a series of lectures before the University of Michigan Library School in March, 1936." $20 \times 12.5 \mathrm{~cm}$.; $56 \mathrm{p}$. + frontispiece, facsimile of letter written by Daniel Boone; green boards; green cloth spine; "Privately printed for the friends of The Torch Press Cedar Rapids, Iowa, Christmas nineteen hundred thirty-six"; "Four hundred copies printed in December nineteen thirty-six by The Torch Press Cedar Rapids Iowa."

1937

A THIRD HANDFUL OF WESTERN BOOKS by J. Christian Bay. $20 \times 12.5$ $\mathrm{cm}$.; 58 p. + frontispiece, photograph of man holding shotgun and smoking pipe; brown boards; grey cloth spine; "Privately printed for the friends of The Torch 
Press Cedar Rapids, Iowa, Christmas nineteen hundred thirty-seven"; "Four hundred copies printed in December nineteen thirty-seven by The Torch Press, Cedar Rapids, Iowa."

\section{8}

THE KOH-I-NOOR OF BOOKS: AN ESSAY IN BIBLIOSOPHICAL ERISTICS by Tydor Debrenowsky, custodian of codices, the Cosmopolis Scholarion. $20 \times 12.5$ cm.; 26 p.; grey boards; blue cloth spine; "Privately printed for the friends of The Torch Press Cedar Rapids, Iowa, Christmas nineteen thirty-eight"; "Four hundred copies printed in December nineteen thirty-eight by The Torch Press Cedar Rapids Iowa."

\section{9}

PIONEER EDUCATION AND LIFE by Daniel Drake. $20 \times 12.5 \mathrm{~cm}$.; $55 \mathrm{p} .+$ frontispiece of Daniel Drake, M.D.; blue boards; blue cloth spine; "Privately printed for the friends of The Torch Press Cedar Rapids, Ia., Christmas nineteen thirty-nine"; "Four hundred copies printed in December nineteen thirty-nine by The Torch Press Cedar Rapids, Iowa."

\section{0}

A TENNYSON-BROWNING ASSOCIATION BOOK by J. Christian Bay. $20 \times 13$ cm.; 16 p. + frontispiece, "Maud, and other poems"; green boards; "Printed for the friends of The Torch Press Christmas nineteen forty." No limiting statement printed in book.

\section{1}

A HEROINE OF THE FRONTIER: MIRIAM DAVIS COLT IN KANSAS, 1856: EXTRACTS FROM MRS. COLT'S DIARIES edited, with an introduction, by J. Christian Bay. $20 \times 12.5 \mathrm{~cm}$.; 58 p. + frontispiece, photograph of Mrs. Miriam Davis Colt, 1879; tan boards; "Privately printed for the friends of The Torch Press Cedar Rapids, Iowa, Christmas nineteen forty-one." No limiting statement printed in book.

\section{2}

THE POST-MORTEM FINDING by George Anthony Zeller with an introduction by J. Christian Bay. $20 \times 12.5 \mathrm{~cm}$.; 34 p. + frontispiece, photograph of Dr. George Anthony Zeller (1858-1938); grey boards; black cloth spine; "Privately printed for the friends of The Torch Press Cedar Rapids, Ia., Christmas nineteen fortytwo"; "Four hundred copies printed in December nineteen forty-two by The Torch Press Cedar Rapids, Iowa."

\section{3}

A DESERTED VILLAGE by Henry Sherman Boutell with an introduction by J. Christian Bay. $20 \times 12.5 \mathrm{~cm}$.; 64 p. + frontispiece, photograph of Henry Sherman Boutell; green boards; green cloth spine; "Privately printed for the friends of The Torch Press Cedar Rapids, Ia., Christmas nineteen forty-three"; "Four hundred copies printed in December nineteen forty-three by The Torch Press Cedar Rapids, Iowa."

THE MYSTERY OF THE IRISH CROWN JEWELS: A CRITICAL PRECIS by J. Christian Bay. $20 \times 12.5 \mathrm{~cm}$.; 53 p.; green boards; green cloth spine; "Privately printed for the friends of The Torch Press Cedar Rapids, Ia., Christmas nineteen forty-four"; "Four hundred copies printed in December nineteen fortyfour by The Torch Press Cedar Rapids, Iowa." 
WHERE DID YOU GET THAT HAT? A symposium by Young E. Allison, Meredith Nicholson. William Fortune, and Harry S. New, edited with some comments by J. Christian Bay. $20 \times 12.5 \mathrm{~cm}$.; 46 p. + frontispiece, "The Famous Allison Hat"; green boards; green cloth spine; "Privately printed for the friends of The Torch Press Cedar Rapids, Iowa, Christmas nineteen forty-five"; "Four hundred copies printed in December nineteen forty-five by The Torch Press Cedar Rapids, Iowa."

1946

IN THE HOUSE OF MEMORIES: TABLE TALK by J. Christian Bay. $20 \times 12.5$ cm.; 37 p. + frontispiece, James M. Barrie "From a hitherto unpublished pencil sketch by G. Stampa"; red boards; black cloth spine; "Privately printed for the friends of The Torch Press Cedar Rapids, Ia., Christmas nineteen forty-six"; "Four hundred copies printed in December nineteen forty-six by The Torch Press Cedar Rapids, Iowa."

\section{7}

POEMS BY ROSWELL MARTIN FIELD: A REVIVAL edited, with an introduction, by J. Christian Bay. $20 \times 12.5 \mathrm{~cm}$.; $40 \mathrm{p}$. + frontispiece, photograph of Roswell Martin Field (about 1900); green boards; green cloth spine; "Privately printed for the friends of The Torch Press Cedar Rapids, Ia., Christmas nineteen forty-seven"; "Four hundred copies printed in December nineteen forty-seven by The Torch Press Cedar Rapids, Iowa."

\section{8}

BIOGRAPHY AND BIOGRAPHIES: HINTS AND INDICATIONS by J. Christian Bay. 20 x $12.5 \mathrm{~cm}$.; 32 p. + frontispiece, "The Laubenheimer Medal of George Washington"; blue boards; black cloth spine; "Privately printed for the friends of The Torch Press Cedar Rapids, Ia., Christmas nineteen forty-eight"; "Four hundred copies printed in December nineteen forty-eight by The Torch Press Cedar Rapids, Iowa."

\section{9}

A VIRTUOSO'S COLLECTION by Nathaniel Hawthorne, with an introduction by J. Christian Bay. 20 x 12.5 cm.; 42 p.; blue boards; black cloth spine; "Privately printed for the friends of The Torch Press Cedar Rapids, Ia., Christmas nineteen forty-nine"; "Four hundred copies printed in December nineteen fortynine by The Torch Press Cedar Rapids Iowa."

\section{0}

JOURNEYS AND VOYAGES TO NATURE: A SURVEY OF ONE HUNDRED BOOKS by J. Christian Bay. $20 \times 12.5 \mathrm{~cm}$.; 67 p. + frontispiece, “Author's Edition of Darwin's "Beagle' Report" + 1 unnumbered page, photograph; blue boards; black cloth spine; "Privately printed for the friends of The Torch Press Cedar Rapids, Ia., Christmas nineteen fifty"; "Four hundred copies printed in December nineteen fifty by The Torch Press Cedar Rapids, Iowa."

1951

GOING WEST: THE PIONEER WORK OF ALFRED BRUNSON briefly interpreted by J. Christian Bay. $20 \times 12.5 \mathrm{~cm}$.; 56 p. + frontispiece; blue boards; black cloth spine; "Privately printed for the friends of The Torch Press Cedar Rapids, Ia., Christmas nineteen fifty-one"; "Four hundred copies printed in December nineteen fifty-one by The Torch Press Cedar Rapids, Iowa."

THE BOOKMAN IS A HUMMINGBIRD: BOOK COLLECTING IN THE 
MIDDLE WEST AND THE HOUSE OF WALTER M. HILL by J. Christian Bay. $20 \times 12.5 \mathrm{~cm}$.; 55 p. + frontispiece, photograph of Walter M. Hill +2 unnumbered pages, photographs; blue boards; blue cloth spine; "Privately printed for the friends of The Torch Press Cedar Rapids, Iowa, Christmas nineteen fiftytwo"; "Four hundred copies printed in December, nineteen fifty-two by The Torch Press Cedar Rapids, Iowa."

GOD SPEEDE THE PLOUGH: (1601) FACSIMILE REPRINT introduction by J. Christian Bay. $20 \times 12.5$ cm.; 30 p. + 16 unnumbered pages, facsimile of "Corl Speede the Plough"; decorated boards; black cloth spine; "Privately printed for the friends of The Torch Press Cedar Rapids, Ia., Christmas nineteen fifty-three"; "Four hundred copies printed in December nineteen fifty-three by The Torch Press Cedar Rapids, Iowa."

THE NORTHERN LAKES: A SUMMER RESORT FOR INVALIDS OF THE SOUTH (1842) by Daniel Drake, reprinted with an introduction by J. Christian Bay. $20 \times 12.5 \mathrm{~cm}$.; 49 p. + frontispiece, photograph of Daniel Drake; red boards; black cloth spine; "Privately printed for the friends of The Torch Press Cedar Rapids, Ia., Christmas nineteen fifty-four"; "Four hundred copies printed in December nineteen fifty-four by The Torch Press Cedar Rapids, Iowa."

1955

THE JOURNAL OF MAJOR GEORGE WASHINGTON OF HIS JOURNEY TO THE FRENCH FORCES ON OHIO, facsimile of the Williamsburg edition 1754, with an introduction by J. Christian Bay. $20 \times 12.5 \mathrm{~cm}$;; $15 \mathrm{p}$. +28 pages of facsimile of journal +1 unnumbered page, facsimile of advertisement for Washington's journal; green boards; black cloth spine; "Privately printed for the friends of The Torch Press Cedar Rapids, Ia., Christmas nineteen fifty-five"; "Four hundred copies printed in December nineteen fifty-five by The Torch Press Cedar Rapids, Iowa."

\section{6}

THE OLD MUSIC MASTER: A SMALL-TOWN CHRISTMAS MEMORY by Young E. Allison, introduction by J. Christian Bay. $20 \times 12.5 \mathrm{~cm} . ; 32 \mathrm{p}$. + frontispiece, photograph of Young E. Allison, 1853-1932; decorated boards; red cloth spine; "Privately printed for the friends of The Torch Press Cedar Rapids, Iowa, Christmas nineteen fifty-six"; "Four hundred copies printed in December nineteen fifty-six by The Torch Press Cedar Rapids, Iowa."

NATIVE FOLK SPIRIT IN LITERATURE: THREE ESSAYS by Meredith Nicholson, Maurice Thompson, and Hamlin Garland, with an introduction by J. Christian Bay. $20 \times 12.5 \mathrm{~cm}$;; 45 p.; blue boards; red cloth spine; "Privately printed for the friends of The Torch Press Cedar Rapids, Ia., Christmas nineteen fifty-seven"; "Three hundred and fifty copies printed in December nineteen fiftyseven by The Torch Press Cedar Rapids, Iowa."

\section{8}

VIRTUES AND FAULTS OF SOME EUROPEAN NATIONS (1743) [by] Ludvig Holberg, now leniently translated with an introduction by J. Christian Bay. 19.5 x 12 cm.; 52 p. + frontispiece, Ludvig Holberg 1684-1754; green boards; red cloth spine; "Privately printed for the friends of The Torch Press Cedar Rapids, Ia., Christmas nineteen fifty-eight"; "Three hundred and fifty copies printed in December nineteen fifty-eight by The Torch Press Cedar Rapids, Iowa." 
CARL SANDBURG ON ABRAHAM LINCOLN: Carl Sandburg's speech before the Congress of the United States, February the Eighteenth, 1959, followed by an introduction by J. Christian Bay. $20 \times 12 \mathrm{~cm}$; $30 \mathrm{p}$. + frontispiece of Carl Sandburg, "Photo by Edward Steichen, 1954"; decorated boards; red cloth spine; "Privately printed for the friends of The Torch Press Cedar Rapids, Ia., Christmas nineteen fifty-nine"; Dedicated "To the memory of Edward F. Misak, 1884-1959"; "Three hundred and fifty copies printed in December nineteen fifty-nine by The Torch Press Cedar Rapids, Iowa."

THE FOSTER CHRISTMAS SERIES (1945-1951)

1945

A LITTLE JOURNEY TO THE CHATEAUX OF THE LOIRE by T. Henry Foster and GARDEN MEMORIES by Mary F. Foster. $32 \mathrm{p}$. + frontispiece of "The Chateau of Chambord" +1 unnumbered page, photograph of "View In Gardens-White Oaks"; $20 \times 12.5 \mathrm{~cm}$.; decorated boards; black cloth spine; "Privately printed for the friends of May and Harry Foster at The Torch Press, Christmas, 1945."

\section{6}

SHAKESPEARE-MAN OF MYSTERY by Thomas Henry Foster. 46 p. + frontispiece, photograph of painting of "Edward deVere, 17th Earl of Oxford"; $21 \times 13$ $\mathrm{cm}$; black decorated boards; black cloth spine; "Privately printed for the friends of May and Harry Foster at The Torch Press, Christmas, 1946"; "This edition is limited to two hundred copies."

\section{7}

AMERICA'S MOST FAMOUS BOOK: A DISSERTATION ON HARRIET BEECHER STOWE, "UNCLE TOM'S CABIN" and UNCLE TOM SHOWS by Thomas Henry Foster. 37 p. + frontispiece, photograph of painting of Harriet Beecher Stowe by John Chapman +3 unnumbered pages of photographs; $20.5 \mathrm{x}$ $12.5 \mathrm{~cm}$; wood grained paper boards; black cloth spine; "Privately printed for the friends of May and Harry Foster at The Torch Press, Christmas, 1947."

1948

BEADLES, BIBLES \& BIBLIOPHILES by Thomas Henry Foster. 48 p. + frontispiece, photograph of cover of January 24, 1883, issue of "The Five Cent Wide Awake Library" +6 unnumbered pages of photographs; $20.5 \times 12.5 \mathrm{~cm}$; blue boards; black cloth spine; "Privately printed at The Torch Press, Christmas, 1948."

A LETTER FROM THE FIRE: BEING AN ACCOUNT OF THE GREAT CHICAGO FIRE written in 1871 by Thomas D. Foster, with an introduction by Thomas Henry Foster. 30 p. + frontispiece, photograph of Thomas D. Foster "from a photograph taken in London, Canada, shortly after the Chicago Fire" + 2 unnumbered pages of photographs; $20.5 \times 12.5 \mathrm{~cm}$; red, white, and blue decorated boards; black cloth spine; "Reprinted from the original edition"; "Privately printed for the friends of May and Harry Foster at The Torch Press Christmas, 1949." 
THE UNBOUGHT GRACE OF LIFE AND OTHER ESSAYS by Thomas Henry Foster with a foreword by Lawrence Oakley Cheever. 72 p. +2 unnumbered pages of photographs; $20.5 \times 12.5 \mathrm{~cm}$; black and white decorated boards; black cloth spine; "Privately printed for the friends of May and Harry Foster at The Torch Press, Christmas, 1950."

\section{1}

DEAR SIR: LETTERS THAT SPEAK with notes by Thomas Henry Foster. 73 p. + frontispiece, facs. of letter by R. F. Outcault +3 unnumbered pages, facs. of letters; $20.5 \times 12.5 \mathrm{~cm}$.; red, white, blue, brown decorated boards; red cloth spine; "Privately printed for the friends of May and Harry Foster at The Torch Press Christmas, 1951."

\section{III}

\section{OTHER LIMITED EDITIONS PRINTED BY THE TORCH PRESS} (Includes only volumes with a stated numerical limitation)

\section{5}

SAVAGE-THE RAKE; CHATTERTON-THE PRECOCIOUS YOUTH: TWO EIGHTEENTH CENTURY CHARACTER SKETCHES by William Harvey Miner. 65 p.; $13 \times 8 \mathrm{~cm}$.; slate-grey boards; brown cloth spine; 200 copies.

A SHELF IN MY BOOKCASE by Alexander Smith. 43 p.; $13 \times 8 \mathrm{~cm}$.; slate-grey boards; white cloth spine; 15 copies.

1906

THE LOVE POEMS OF SIR JOHN SUCKLING. 66 p.; $13 \times 8 \mathrm{~cm}$.; marbled boards; white paper spine and corners; 20 copies.

OSCAR WILDE: A SKETCH, WITH NOTICES OF SOME OF HIS BOOKS by Willis Vickery. 49 p.; $13 \times 8 \mathrm{~cm}$.; slate-grey boards; brown cloth spine; 225 copies.

SOME AUTUMN DAYS IN IOWA by Frederick John Lazell. [Cedar Rapids: The Ioway Club] 33 p.; $24 \times 15 \mathrm{~cm}$; grey-green boards; green cloth spine; gilt top; 75 copies.

\section{7}

CHARLES CHURCHILL, VAGABOND POET by William Harvey Miner. 42 p.; $13 \times 8 \mathrm{~cm}$; s slate-grey boards; brown cloth spine; 200 copies.

IN PRAISE OF VALOR: AN ORATION by Rev. Thomas Edward Green, D.D. [Cedar Rapids: The loway Club] 24 p.; $23.5 \times 15 \mathrm{~cm}$; green boards; orange cloth spine; gilt top; 75 copies.

1908

ACCOUNT OF THE BALL GIVEN IN HONOR OF CHARLES DICKENS IN NEW YORK CITY FEBRUARY 14, 1842 from the New York Aurora-Extra. 64 p. +; $24 \times 15.5 \mathrm{~cm}$.; grey boards; white cloth spine; 206 copies.

1909

EDGAR ALLAN POE by Edmund Clarence Stedman. 95 p.; $20.5 \times 13 \mathrm{~cm}$; dark green cloth; gilt top; 200 copies.

AN EXHIBITION OF FINE BINDINGS [Cleveland: The Rowfant Club] [42 
p.] $22.5 \times 15 \mathrm{~cm}$; ivory paper wrapper, with photographic plaque attached to front cover; 100 copies.

NARRATIVE OF MR. JOHN DODGE DURING HIS CAPTIVITY AT DETROIT, with an Introductory Note by Clarence Monroe Burton. 64 p.; $26.5 \times 21$ cm.; brown boards; black cloth spine; boxed; 63 copies.

\section{0}

ABRAHAM LINCOLN: A CONTRIBUTION TOWARD A BIBLIOGRAPHY by L. E. Russell [Cedar Rapids. Iowa: The Torch Press Book Shop] 24 p.; $16.5 \times 10.5$ cm.; tan boards; green spine; 50 copies in boards.

EDWARD O. MANSFIELD [Cedar Rapids, Iowa: Privately Printed] 48 p.; 20.5 x $13 \mathrm{~cm}$; full black leather; 125 copies.

J. WINFRED SPENCELEY: HIS ETCHINGS AND ENGRAVINGS IN THE FORM OF BOOK PLATES [New York: Privately Printed] 134 p.; 24 x 10.5 cm.; brown hoards; vellum spine; gilt top; 100 copies.

1911

LETTERS FROM FRANCIS PARKMAN TO E. G. SQUIER, with Biographical Notes and a Bibliography of E. G. Squier by Don C. Seitz. 58 p.; $24.5 \times 16 \mathrm{~cm}$.; grey boards; grey cloth spine; 200 copies.

\section{2}

ANNA MARCELLA'S BOOK OF VERSES by Cyrenus Cole, Her Friend. 187 p; $20 \times 13 \mathrm{~cm}$; grey marbled boards; vellum spine and corners; gilt top; slipcased; 125 copies.

1913

A DISCOURSE OF FRIENDSHIP by Jeremy Taylor, with an Introduction by Wm. H. Powers [Printed for J. L. Powers and his friends] 82 p.; $19 \times 11 \mathrm{~cm}$; grey boards; paper label; 25 copies.

KENTUCKY IN AMERICAN LETTERS, 1784-1912 by John Wilson Townsend, with an Introduction by James Lane Allen. 2 vols., 368 and 394 p.; $24.5 \times 16 \mathrm{~cm}$;; brown boards; green cloth spines (sets also with red or brown spines); 1000 copies.

TWELFTH YEAR BOOK, 1913 [Boston: The Bibliophile Society] 148 p.; $23 \times 16$ cm.; cream-colored boards; 500 copies.

1914

AUTUMN NOTES IN IOWA by Selden Lincoln Whitcomb. 192 p.; $20 \times 13.75$ cm.; tan cloth; 500 copies.

BOOKPLATES IN IOWA by Malcolm G. Wyer; with a Chapter on the Pleasure of Collecting by T. Henry Foster. 56 p.; $21 \times 14 \mathrm{~cm}$; brown boards; 100 copies.

1915

MARSHALI, GROUCHY'S OWN ACCOUNT OF THE BATTLE OF WATERLOO. 15 p.; $23.5 \times 17$ cm.; white boards; 200 copies.

MEDITATIONS ON THE VIA CRUCIS by Selden L. Whitcomb. 47 p.; $21 \times 14$ cm.; grey cloth; 350 copies.

1916

A DISSERTATION UPON ROAST PIG by Charles Lamb. 24 p.; 22.5 x $14.5 \mathrm{~cm}$; blue and pink marbled boards; vellum spine; 25 copies. 


\section{7}

THE CHOICE OF PARIS AND OTHER POEMS by D. C. Chase. 56 p.; $23 x$ $16.25 \mathrm{~cm}$; brown boards; vellum spine; 100 copies.

1919

A LITTLE BOOK OF BOOKLY VERSE: CONTRIBUTED BY SEVERAL OF THE BOOKFELLOWS TO HELP MAKE CHRISTMAS MERRY. [Chicago: The Bookfellows] 16 p.; $20.5 \times 14$ cm.; dark brown wrapper; paper label; 500 copies.

ADVENTURES WITH BOOKS AND AUTOGRAPHS by George Steele Seymour. [Chicago: The Bookfellows] 81 p.; $20 \times 14 \mathrm{~cm}$; dark green boards; grey cloth spine; paper labels; 500 copies.

ECHOES OF ROBERT LOUIS STEVENSON by J. Christian Bay. [Chicago: Walter M. Hill] 93 p.; $20 \times 12 \mathrm{~cm}$.; dark blue boards; brown cloth spine; 515 copies.

ENGLISH NOTES: A RARE AND UNKNOWN WORK BEING A REPLY TO CHARLES DICKENS'S “AMERICAN NOTES," with critical comments by Joseph Jackson and George H. Sargent, and Two Portraits. [New York City: Lewis M. Thompson] 182 p.; $21.5 \times 14 \mathrm{~cm}$.; tan boards; 100 copies.

ESTRAYS [by] Thomas Kennedy, George Seymour, Vincent Starrett [and] Basil Thompson. [Chicago: The Bookfellows] 46 p.; $19.5 \times 12 \mathrm{~cm}$.; tan boards; tan cloth spine; paper labels; 300 copies.

LITTLE DUST AND OTHER POEMS by Richard R. Kirk. with Decorations by Jan W. Vonesh. [Chicago: The Bookfellows] 14 p.; 20.5 x $14 \mathrm{~cm}$.; blue paper wrapper; paper label; 1000 copies.

THE NINETEENTH YEAR BOOK. 1920. [Boston: The Bibliophile Society] 146 p.; $2.3 \times 16 \mathrm{~cm}$.; cream paper-covered boards; slipcased; 500 copies.

1921

EARLY PRINTED BOOKS; Annotated Catalogue [April, 1921] with Introduction and Epilogue [Chicago: Walter M. Hill] 103 p.; 24 x $16 \mathrm{~cm}$.; blue boards; white label; 75 numbered copies.

GRIFFONAGE by Burton Haseltine, drawings by Mildred Ross. [Chicago: The Bookfellows] 20 unnumbered leaves printed on one side only; $24 \times 16 \mathrm{~cm}$; grey boards; black cloth spine; 300 copies.

LAUREATE ADDRESS OF JOHN G. NEIHARDT, UPON OFFICIAL NOTIFICATION OF HIS CHOICE AS POET LAUREATE OF NEBRASKA. [Chicago: The Bookfellows] 49 p.; $20 \times 12.5 \mathrm{~cm}$.; green boards; green cloth spine; 500 copies.

THE POET'S PACK. John G. Neihardt, Editor-in-Chief. [Chicago: The Bookfellows] 148 p.; $20.25 \times 14$ cm.; grey-green boards; grey cloth spine; paper labels; 500 copies.

SAY NOW SHIBBOLETH by Eugene Manlove Rhodes. [Chicago: The Bookfellows] 55 p.; $19.25 \times 12.25$ cm.; grey boards; grey cloth spine; paper labels; 400 copies.

STEVENSON AT MANASQUAN by Charlotte Eaton. [Chicago: The Bookfellows] 48 p.; 19.5 x 12 cm.; blue boards; blue cloth spine; paper labels; 300 copies. STEVENSON'S WORKSHOP, with Twenty-Nine Ms. Facsimiles, edited by William P. Trent. [Boston: The Bibliophile Society] $63 \mathrm{p} .+$ +; $23 \times 18 \mathrm{~cm}$; brown cloth; white paper spine and corners; slipcased; 450 copies. 
BALLADS OF ROBIN HOOD by Leigh Hunt, with Some Manuscript Reproductions. 32 p.; $20 \times 14 \mathrm{~cm}$; blue paper wrapper; 200 copies.

A BIBLIOGRAPHY OF THE WORKS OF JOSEPH HERGESHEIMER by H. L. R. Swire. [Philadelphia: The Centaur Book Shop] 39 p.; $19.5 \times 12 \mathrm{~cm}$; winecolored boards; wine cloth spine; paper labels; 300 copies (also 35 large paper copies?).

JOHN H. MORRELL (1864-1921). [Privately Printed] 25 p.; $20 \times 12.5 \mathrm{~cm}$.; grey wrapper; 150 copies.

THE LAURA BLACKBURN 1921 PRIZE LYRICS. [Chicago: The Bookfellows] 15 p.; $24 \times 16 \mathrm{~cm}$.; brown wrappers; 400 copies.

A PIONEER MOTHER by Hamlin Garland. [Chicago: The Bookfellows] 21 p.; $23.5 \times 14 \mathrm{~cm}$; brown boards; brown cloth spine; 525 copies.

A WREATH FOR EDWIN MARKHAM: TRIBUTES FROM THE POETS OF AMERICA ON HIS SEVENTIETH BIRTHDAY, APRIL 23, 1922. [Chicago: The Bookfellows] 47 p.; $24 \times 16 \mathrm{~cm}$; blue boards; blue cloth spine; 300 copies.

1923

BANNERS IN THE DAWN: SIXTY-FOUR SONNETS by Vincent Starrett. [Chicago: Walter M. Hill] 73 p.; $19.75 \times 14$ cm.; brown boarcls; purple paper spine; 250 copies.

CHRONICLES OF BAGDAD: AN ORIENTAL FANTASY by Abdu'l Hassan [Chicago: The Bookfellows] il3 p.; $19 \times 12 \mathrm{~cm}$.; green boards; green cloth spine; paper labels; 350 copies.

THE LAURA BLACKBURN 1922 PRIZE LYRICS. [Chicago: The Bookfellows] 15 p.; $23.5 \times 16 \mathrm{~cm}$.; brown wrapper; 399 copies.

PARNASSIANS PERSONALLY ENCOUNTERED by Edgar Saltus. 29 p.; $20 \mathrm{x}$ $13.5 \mathrm{~cm}$.; green boards; white paper spine; 200 copies.

PERSONS FROM PORLOCK by Vincent Starrett. [Chicago: The Bookfellows] 16 p.; $24.5 \times 16 \mathrm{~cm}$; grey wrapper; 300 copies.

POPE'S EPISTLE, ELOISA TO ABELARD, with Introduction and Notes by Henry Howard Harper, Original Copperplate Etchings by W. H. W. Bicknell. [Boston: The Bibliophile Society] 50 p.; $22.5 \times 16 \mathrm{~cm}$; brown suede; gilt top; slipcased; 455 copies.

STEPHEN CRANE: A BIBLIOGRAPHY, Compiled with an Introduction by Vincent Starrett. [Philadelphia: The Centaur Book Shop] 46 p.; $23.75 \times 16 \mathrm{~cm}$.; blue boards; blue cloth spine; paper labels; 35 large-paper copies (also $300 \mathrm{reg}$ ular copies ).

TRUTH, by George Sterling [Chicago: The Bookfellows] 124 p.; $24 \times 16 \mathrm{~cm}$; blue boards; buckram spine; paper labels; 285 copies. [Not seen]

1924

ABU HASSAN by Washington Irving (Hitherto Unpublished), with an Introduction by George S. Hellman. [Boston: The Bibliophile Society] 83 p.; 24 x $16 \mathrm{~cm}$; green cloth; vellum spine; slipcased with The Wild Huntsman; 455 copies.

A BIBLIOGRAPHY OF THE WRITINGS OF CARL VAN VECHTEN by Scott Cunningham, with an Overture in the form of a funeral march by Carl Van Vechten. [Philadelphia: The Centaur Book Shop] 52 p.; $19.25 \times 12.25 \mathrm{~cm}$.; green boards; silver paper labels; 300 copies (also 85 large-paper copies).

A BIBLIOGRAHY OF THE WRITINGS OF H. L. MENCKEN by Carroll Frey, with a Foreword by H. L. Mencken. [Philadelphia: The Centaur Book Shop] 70 
p.; $19.25 \times 12.25 \mathrm{~cm}$; black boards; black cloth spine; gold paper labels; 300 copies (also 85 large-paper copies).

A BIBLIOGRAPHY OF THE WRITINGS OF JAMES BRANCH CABELL by Guy IIolt. [Philadelphia: The Centaur Book Shop] 73 p.; 19.25 x $12.25 \mathrm{~cm}$; brown boards; brown cloth spine; paper labels; 500 copies (including 100 large-paper copies).

BRASS TACKS BALLADS by Edmund Vance Cooke. [Chicago: The Bookfellows] 27 p.; $20 \times 13.5 \mathrm{~cm}$; grey wrapper; 325 copies.

A CHRISTMAS SYMPHONY by A. Francis Trams. 25 p.; $21.5 \times 14.25 \mathrm{~cm}$.; brown wrapper; 100 copies.

THE DEVIL'S NEST (A NOVEL) with etched frontispiece by W. H. W. Bicknell. Second edition. 312 p.; $24 \mathrm{~cm}$; 100 copies. [Not seen]

IT WAS HIS BIRTHDAY by Alice Wilson Oldroyd, Decoration by Marjorie Howe Dixon. [Chicago: The Bookfellows] 8 p.; $24 \times 15.5 \mathrm{~cm}$.; buff wrapper; 1000 copies. THE LEGEND OF THE BOOK by Gilbert Harry Doane and Eloise White Street. with Illustrations by John W. Alexander. [Chicago: The Bookfellows] 30 p.; $19.5 \mathrm{x}$ $12.25 \mathrm{~cm}$; grey marbled boards; chocolate-brown cloth spine; paper labels; 300 copies.

THE PEARL HUNTER by Paul Wright. [Chicago: Privately Printed] 8 p.; $22 x$ $15 \mathrm{~cm}$.; blue wrapper; 50 copies.

THE [ROWFANT CLUB] YEAR BOOK FOR 1923. [Cleveland: The Rowfant Clul)] 112 p.; $18.5 \times 12$ cm.; blue boards; cream-colored cloth spine; paper labels; I25 copies.

THE WILD HUNTSMAN by Washington Irving (Hitherto Unpublished). with an Introduction by George S. Hellman. [Boston: The Bibliophile Society] 113 p.; $24 \times 16 \mathrm{~cm}$; green cloth; vellum spine; slipcased with Abu Hassan; 455 copies.

1925

A BIBLIOGRAPHY OF THE WRITINGS OF D. H. LAWRENCE by Edward D. McDonald, with a Foreword by D. H. Lawrence. [Philadelphia: The Centaur Book Shop] 145 p.; $19 \times 12 \mathrm{~cm}$; dark blue boards; buff cloth spine; paper labels; 500 copies (including 100 large-paper copies).

A BOOKFELLOW ANTHOLOGY, 1925. [Chicago: The Bookfellows] 222 p.; $19.75 \times 13.5 \mathrm{~cm}$; blue cloth; 700 copies.

DREAMS THAT LIVE by Ralph Culnan. [Chicago: Private Edition] 48 p.; $24 \mathrm{x}$ $16 \mathrm{~cm}$; blue boards; blue cloth spine; paper labels; 200 copies.

DROWSY ONES by Jay G. Sigmund. [Cedar Rapids: Prairie Publishing Company] 48 p.; $19 \times 12.5$ cm.; marbled boards; white cloth spine; paper labels; 325 copies.

THE EAGLE FLIES: SONNETS by Clement Wood. [Chicago: The Bookfellows] [24 p.] $19 \times 13.5 \mathrm{~cm}$; blue wrapper; paper label; 300 copies.

THE ENCHANTED GARDEN by John Erskine. [Chicago: The Bookfellows] 75 p.; $24 \times 16$ cm.; marbled boards; grey cloth spine; paper labels; 300 copies.

LINCOLN BIBLIOGRAPHY: A LIST OF BOOKS AND PAMPHLETS RELATING TO ABRAHAM LINCOLN compiled by Joseph Benjamin Oakleaf of the Illinois Bar. 424 p.; $24 \times 16 \mathrm{~cm}$; blue buckram; black morocco spine and corners; 102 copies.

THE [ROWFANT CLUB] YEAR BOOK FOR 1924. [Cleveland: The Rowfant Club] 104 p.; $18 \times 11.5 \mathrm{~cm}$.; blue boards; tan cloth spine; paper labels; slipcased; 125 copies. 
A BIBLIOGRAPHY OF BOOKPLATE LITERATURE edited, with a Foreword, by George W. Fuller, Bibliographical Work by Verna B. Grimm, Some Random Thoughts on Bookplate Literature by Winward Prescott. [Spokane: Public Library] 151 p.; $23.5 \times 16 \mathrm{~cm}$; red cloth; gilt top; 500 copies.

A BOOKFELLOW ANTHOLOGY, 1926. [Chicago: The Bookfellows] 262 p.; $20 \times 13.5 \mathrm{~cm}$; ; blue cloth; 800 copies.

FAGOTS OF CEDAR, Bookfellow Edition, by Ivan Swift. [Goodhart, Michigan: Printed for The Lofts, Chippewa Cove Woods] 58 p.; $22.5 \times 15.5 \mathrm{~cm}$.; $\tan$ boards; tan cloth spine; 500 copies.

NOTES FOR A NEW MYTHOLOGY by Haniel Long. [Chicago: The Bookfellows] 167 p.; $23.75 \times 16 \mathrm{~cm}$; black boards; black cloth spine; paper labels; 4.35 copies.

A TALLOW DIP by Richard R. Kirk. [Chicago: The Bookfellows] [36 p.] $19 \times 12$ cm.; brown stiff paper; white label; 675 copies.

\section{7}

A BIBLIOGRAPHY OF THE WRITINGS OF NORMAN DOUGLAS by Edwar( D. McDonald. [Philadelphia: The Centaur Book Shop] 165 p.; $19 \times 12 \mathrm{~cm}$.; blue cloth; paper label; 300 copies (also 100 large-paper copies).

A BOOKFELLOW ANTHOLOGY, 1927. [Chicago: The Bookfellows] 222 p.; $20 \times 13.5 \mathrm{~cm}$; blue cloth; 800 copies.

LEIGH HUNT'S LETTER ON HOGG'S LIFE OF SHELLEY, WITH OTHER PAPERS. 32 p.; $23.5 \times 16 \mathrm{~cm}$; green cloth; vellum spine; 100 copies.

SONGS FROM THE STEP LADDER. [Chicago: The Bookfellows] 112 p.; $23 \mathrm{x}$ $16 \mathrm{~cm}$.; brown boards; brown cloth spine; slipcased; 285 copies.

STRAIGHT IN THE SADDLE by Marion Frances Brown. [Chicago: The Bookfellows] 35 p.; $19.5 \times 13 \mathrm{~cm}$; blue marbled wrapper; 25 copies (de luxe edition).

1928

A BIBLIOGRAPHY OF THE WRITINGS OF THEODORE DREISER by Edward D. McDonald, with a Foreword by Theodore Dreiser. [Philadelphia: The Centaur Book Shop] 130 p.; $19 \times 12 \mathrm{~cm}$; green cloth; paper label; 350 copies.

A BOOKFELLOW ANTHOLOGY, 1928. [Chicago: The Bookfellows] 185 p.; $19.75 \times 13.5 \mathrm{~cm}$; blue cloth; 600 copies.

ESSAYS OF OLIVER GOLDSMITH. [Boston: The Bibliophile Society] 2 vols., 277 p. and 188 p.; $22.5 \times 15.5 \mathrm{~cm}$; blue cloth; vellum spine; 400 copies.

$$
1929
$$

AMBROSE BIERCE: A BIBLIOGRAPHY by Vincent Starrett. [Philadelphia: The Centaur Book Shop] 117 p.; 300 copies (also 45 large-paper copies). [Not seen] A BOOKFELLOW ANTHOLOGY, 1929. [Chicago: The Bookfellows] 222 p.; $20 \times 13.5 \mathrm{~cm}$; blue cloth; 700 copies.

THE CHARITY OF CHARLES DICKENS: HIS INTEREST IN THE HOME FOR FALLEN WOMEN, AND A HISTORY OF THE STRANGE CASE OF CAROLINE MAYNARD THOMPSON by Edward F. Payne and Henry H. Harper. [Boston: The Bibliophile Society] 100 p.; $23 \times 16 \mathrm{~cm}$.; full leather; gilt top; slipcased; 425 copies.

THE MANUSCRIPTS OF ROBERT LOUIS STEVENSON'S RECORDS OF A FAMILY OF ENGINEERS: THE UNFINISHED CHAPTERS edited with an Introduction by J. Christian Bay. [Chicago: Walter M. Hill] 92 p.; 28 x $20.5 \mathrm{~cm}$; marbled boards; black cloth spine; 300 copies. 
THE ROMANCE OF CHARLES DICKENS AND MARIA BEADNELL WINTER by Edward F. Payne and Henry H. Harper. [Boston: The Bibliophile Society] 177 p.; $23 \times 16 \mathrm{~cm}$; full leather; gilt top; slipcased; 425 copies.

SAMUEL JOHNSON, PRESIDENT OF KING'S COLLEGE: HIS CAREER AND WRITINGS edited by Herbert and Carol Schneider, with a Foreword by Nicholas Murray Butler. [New York: Columbia University Press] 4 volumes, 526 p., 603 p., 641 p., 797 p.; $22.5 \times 15 \mathrm{~cm}$.; $\tan$ cloth; brown cloth spine; 500 copies.

\section{0}

A BOOKFELLOW ANTHOLOGY, 1930. [Chicago: The Bookfellows] 188 p.; $20 \times 13.5 \mathrm{~cm}$.; lavender marbled cloth; 600 copies.

CHORDS AND DISCORDS by A. Nicoll Weeber. 64 p.; $19 \times 13 \mathrm{~cm}$; brown marbled boards; brown cloth spine; silver labels (also copies in full red leather); 300 copies.

THE CONSOLATION OF PHILOSOPHY by Boethius, translation of $H$. R. James, M.A. [Boston: The Bibliophile Society] 208 p.; 25.5 x $19.5 \mathrm{~cm}$.; blue cloth; vellum spine; slipcased with Dante's New Life; 433 copies.

DANTE'S "NEW LIFE," with a commentary by Henry Howard Harper, including echoes and love laments of the early Italian Renaissance. [Boston: The Bibliophile Society] 148 p.; $25.5 \times 19.5 \mathrm{~cm}$; blue cloth; vellum spine; slipcased with Boethius, Consolation of Philosophy; 433 copies.

1931

A BOOKFELLOW ANTHOLOGY, 1931. [Chicago: The Bookfellows] 208 p.; $20 \times 13.5 \mathrm{~cm}$; lavender marbled cloth; 600 copies.

THE WRITINGS OF D. H. LAWRENCE, 1925-1930: A BIBLIOGRAPHICAL SUPPLEMENT by Edward D. McDonald. [Philadelphia: The Centaur Book Shop] 134 p.; $19 \times 12 \mathrm{~cm}$.; red boards; buff cloth spine; paper labels; 350 copies (also 60 large-paper copies).

1932

A BIBLIOGRAPHY OF THE WRITINGS OF JAMES BRANCH CABELL: A REVISED BIBLIOGRAPHY by I. R. Brussel. [Philadelphia: The Centaur Book Shop] 133 p.; $19 \times 12 \mathrm{~cm}$.; green cloth; paper label; 350 copies.

A BOOKFELLOW ANTHOLOGY, 1932. [Chicago: The Bookfellows] 186 p.; $20 \times 13.5 \mathrm{~cm}$; lavender marbled cloth; 600 copies.

MY LEIGH HUNT LIBRARY: THE FIRST EDITIONS, Collected and Described by Luther A. Brewer, with 100 Illustrations. 391 p.; $26 \times 17.75 \mathrm{~cm}$; red buckram; yellow top; 125 copies.

A NARRATIVE OF THE LIFE OF J. LOWE WHITE, 1850-1932 by J. Lowe White. 182 p.; $24 \times 16 \mathrm{~cm}$; blue cloth; vellum spine and tips; gilt top; slipcased; 50 copies.

1933

A BOOKFELLOW ANTHOLOGY, 1933. [Chicago: The Bookfellows] $140 \mathrm{p}$; $20 \times 13.5 \mathrm{~cm}$; ; blue cloth; 400 copies.

LA BELLA SIMONETTA AND OTHER POEMS by Charles Granger Blanden. [Chicago: The Bookfellows] 137 p.; $19.25 \times 12 \mathrm{~cm}$.; tan boards; tan cloth spine; paper labels; 150 copies.

A BOOKFELLOW ANTHOLOGY, 1934. [Chicago: The Bookfellows] 176 p.; $20 \times 13.5 \mathrm{~cm}$.; blue cloth; 400 copies. 
DE SMAA TING OG ANDRE SMAATING [by] C. H. W. Hasselriis. [New York: 18 Beechknoll Road, Forest Hills Gardens, L.I.] 36 p.; $20 \times 14$ cm.; rosecolored wrapper; paper label; 200 copies.

THE HENCHMAN OF THE MOON: A POETIC DRAMA IN FIVE ACTS by Antoinette Quinby Scudder. [Chicago: The Bookfellows] 110 p.; $18.5 \mathrm{~cm}$.; 300 copies. [Not seen]

\section{5}

A BOOKFELLOW ANTHOLOGY, 1935. [Chicago: The Bookfellows] 190 p.; $20 \times 13.5 \mathrm{~cm}$; ; blue cloth; 450 copies.

\section{6}

A BOOKFELLOW ANTHOLOGY, 1936. [Chicago: The Bookfellows] 144 p.; $20 \times 13.5 \mathrm{~cm}$; blue cloth; 350 copies.

POETRY AND EVERYMAN [by] C. H. W. Hasselriis. 30 p.; $20 \times 14 \mathrm{~cm}$.; grey wrapper; paper label; 100 copies.

\section{7}

THE TRYAL OF OLD FATHER CHRISTMAS by Walter W. Schmauch. [Chicago: Walter M. Hill] 128 p.; $19.5 \times 13.5$ cm.; red cloth; gilt top; 500 copies.

1938

THE BOOKFELLOW POETRY ANNUAL, 1938: THE FIRST ISSUE. [Chicago: The Bookfellows] 190 p.; $20 \times 13.5 \mathrm{~cm}$.; brown cloth; 490 copies.

1939

THE BOOKFELLOW POETRY ANNUAL, 1939: THE SECOND ISSUE. [Chicago: The Bookfellows] 166 p.; $20 \times 13.5$ cm.; brown cloth; 490 copies.

1940

THE BOOKFELLOW POETRY ANNUAL, 1940: THE THIRD ISSUE. [Chicago: The Bookfellows] 169 p.; $20 \times 13.5 \mathrm{~cm}$; brown cloth; 400 copies.

1941

THE BOOKFELLOW POETRY ANNUAL, 1941: THE FOURTH ISSUE. [Chicago: The Bookfellows] 170 p.; $20 \times 13.5 \mathrm{~cm}$; brown cloth; 400 copies.

REMEMBER ME? by Alvia Bartholomew Matthews. 64 p.; $19.5 \times 13.5 \mathrm{~cm}$.; silver and green boards; 1000 copies.

THREE HANDFULS OF WESTERN BOOKS by J. Christian Bay, with an Index by Ronald Todd. Second edition [Reprinted from The Fortune of Books]; 125 p.; $23.75 \times 16 \mathrm{~cm}$.; blue boards; blue cloth spine; paper labels; 35 copies.

\section{2}

THE BOOKFELLOW POETRY ANNUAL, 1942: THE FIFTH ISSUE. [Not seen]

1943

THE BOOKFELLOW POETRY ANNUAL, 1943: THE SIXTH ISSUE. [Chicago: The Bookfellows] 167 p.; $20 \times 13.5$ cm.; brown cloth; 430 copies.

1944

THE BOOKFELLOW POETRY ANNUAL, 1944: THE SEVENTH ISSUE. [Chicago: The Bookfellows] 166 p.; 20 x 13.5 cm.; brown cloth; 440 copies. 
THE BOOKFELLOW POETRY ANNUAL, 1945: THE EIGHTH ISSUE. [Not seen]

\section{6}

THE BOOKFELLOW POETRY ANNUAL, 1946: THE NINTH ISSUE [Chicago: The Bookfellows] 158 p.; $20 \times 13.5 \mathrm{~cm}$; brown cloth; paper jacket; 425 copies.

1948

THE MILLWHEEL TURNS by Sadie Fuller Seagrave. 15 p.; $20 \times 13.5 \mathrm{~cm}$; orange wrapper; 200 copies.

\section{2}

THE WORK OF A MAN [by] Jacob A. Riis. 8 p.; 17 x 11 cm.; blue wrapper; 40 copies.

\section{4}

TIMBERLINE: SELECTED VERSE by Rosa Zagnoni Marinoni, Poet Laureate of Arkansas. 261 p.; $22.75 \times 15 \mathrm{~cm}$; black cloth; red top; black and silver dust jacket; 500 copies.

\section{ADDENDA}

1920

THE JUDGING OF JURGEN by James Branch Cabell. [Chicago: The Bookfellows] 13 p.; $28 \times 21.5 \mathrm{~cm}$.; brown boards; dark red cloth spine; paper label; 6 large-paper copies. Inserted in Luther Brewer's copy is a letter from James Branch Cabell to G. S. Seymour which states, inter alia: "This morning I had a note from Mencken protesting that you somehow secured the only remaining printer in Christendom who understands his business."

1921

JOSEPH HERGESHEIMER: AN ESSAY IN INTERPRETATION by James Branch Cabell. [Chicago: The Bookfellows] 27 p.; $20.5 \times 14$ cm.; buff boards; 1,000 copies (also 99 large-paper copies). 


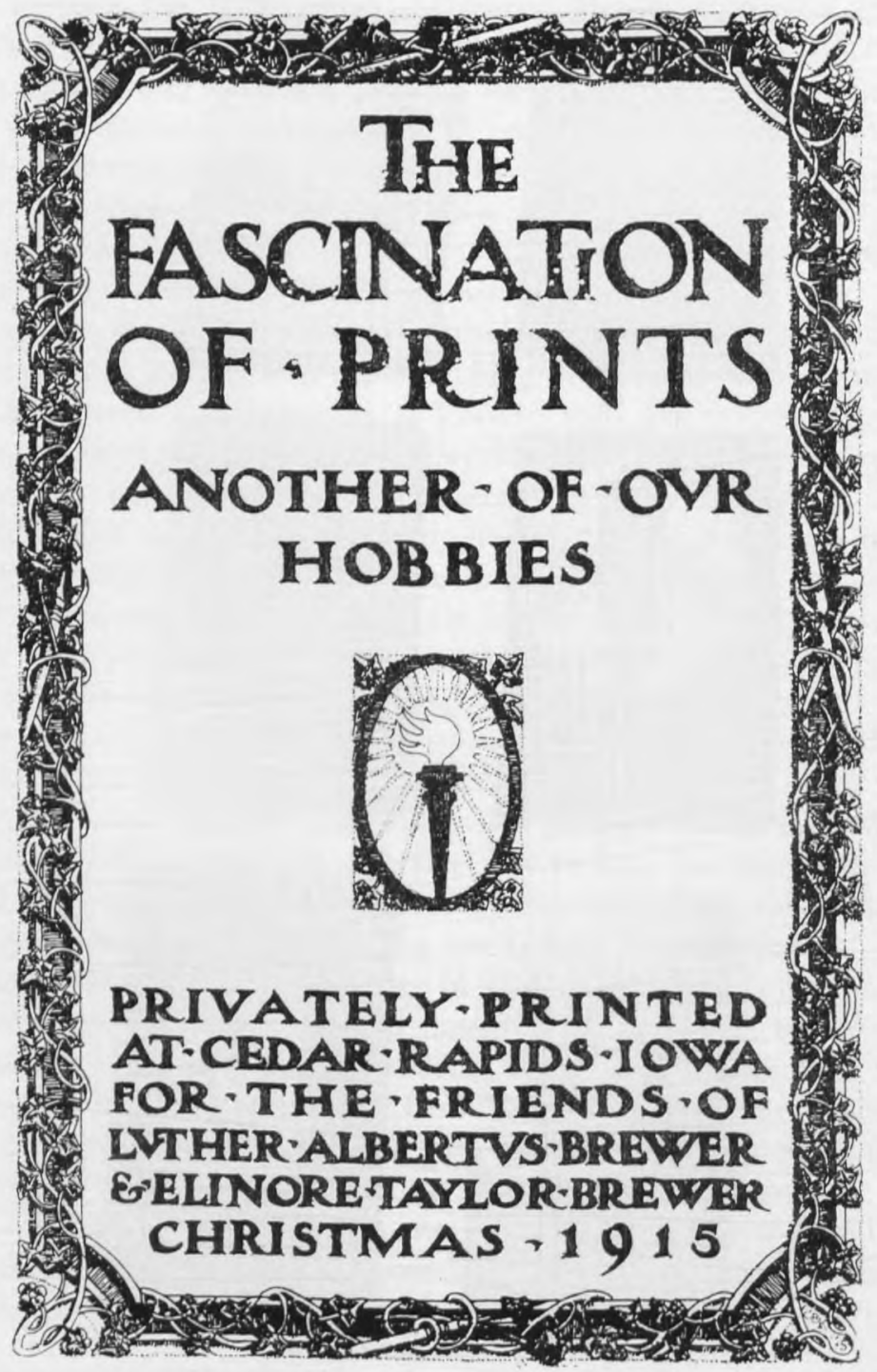

Title page of Luther and Elinore Brewer's Christmas book for 1915. The design was etched by Charles Butler Keeler, and one hundred and seventy copies of the volume were printed at The Torch Press. 


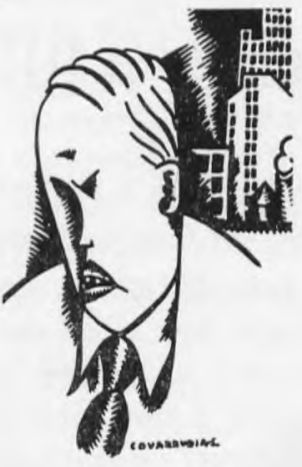

A Bibliography

of the Writings of

Carl Van Vechten

By
Scott Cunningham

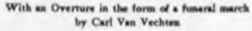

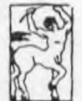

PHILADELPHIA

THE. CENTAUR BOOK SHOP

1924
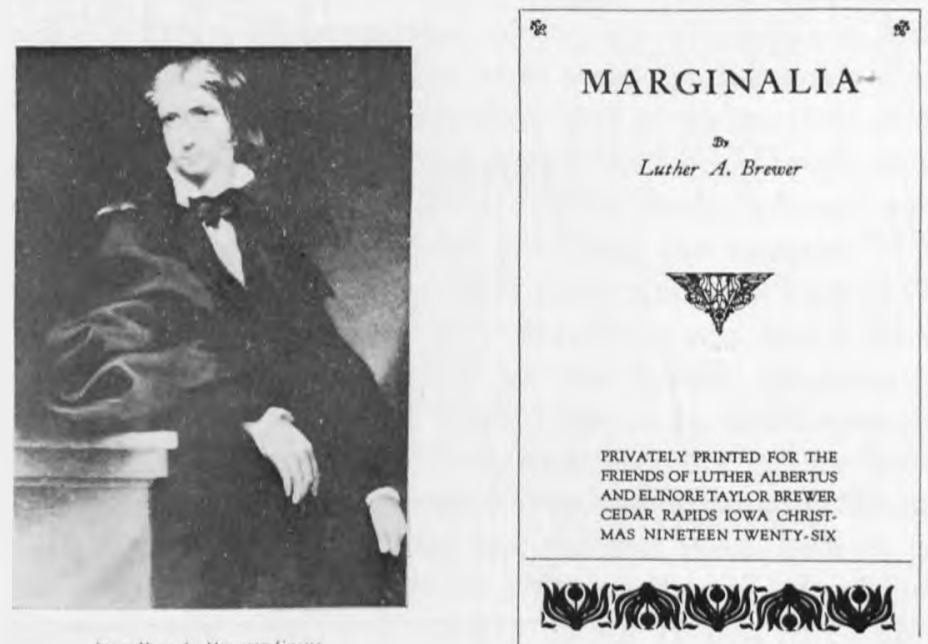

Frontispiece and title page of two limited editions printed at The Torch Press. The frontispiece of the book at the top is a sketch of Carl Van Vechten by Covarrubias, and the portrait of Leigh Hunt which serves as frontispiece to the lower volume is from a painting by Margaret Gillies. 